\title{
Influence of Metabolic Parameters in Repeat Breeding Crossbred Dairy Cows
}

\author{
M. Sameer Ali ${ }^{1 *}$, K. Kulasekar ${ }^{2}$, K. Krishnakumar ${ }^{3}$ and M. Chandrasekar ${ }^{4}$ \\ ${ }^{1}$ Department of Veterinary Gynaecology and Obstetrics, ${ }^{2}$ Department of Clinics, ${ }^{4}$ Department \\ of Clinical Medicine, Madras Veterinary College, Chennai, Tamil Nadu, India \\ ${ }^{3}$ CBBU, Post Graduate Research Institute in Animal Sciences, \\ Kattupakkam, Tamil Nadu, India \\ *Corresponding author
}

\section{A B S T R A C T}

Keywords

Metabolic parameters, Breeding, Crossbred, Dairy cows

Article Info

Accepted:

12 July 2018

Available Online:

10 August 2018
The objective of the present study is to assess the influence of metabolic parameters in repeat breeding crossbred cows according to their body condition score. A total of 136 healthy repeat breeding crossbred cows were selected and divided into five groups based on boy condition score viz, Group I: < 2.50 units, Group II: 2.50 units, Group III: 3.00 units, Group IV: 3.50 units and Group V: > 3.50 units. The concentration of blood glucose, $\beta$-hydroxy butyrate and blood urea nitrogen were estimated. There was no significant difference in the blood glucose, BHB and BUN levels between groups and there was no correlation between these parameters.

\section{Introduction}

Energy status in dairy cows is of utmost importance, it has a direct relationship with milk production, metabolic disease risk, and reproductive performance. High-yielding dairy cows experience a substantial increase in energy requirements during early lactation (between 4 and 8 weeks postpartum) to facilitate the dramatic increase in daily milk yield, which is met by increased feed consumption partially with the remainder being met by mobilisation of body reserves resulting in animals entering negative energy balance (NEB). (Grummer, 2007) Increased risk of metabolic diseases, reduced immune function and a reduction in subsequent fertility are consequence of severe NEB. (Roche et al., 2009) Hence the monitoring of optimal management of energy reserves is obviously needed.

We need an efficient and practically applicable tool to estimate the body reserves 
in dairy cows. (Busato et al., 2002) Even though body weight measurements are routinely used to monitor the changes in those reserves, which is influenced by factors other than the fluctuations of the body fat amount, including changes in the endogenous protein and water contents, gastrointestinal content, changing organ weights, foetal development and frame size. (Schroder and Staufenbiel, 2006)

Indirect measures of energy reserves are always retrospective; instead the metabolic and hormonal factors might be used to assess the energy balance in a properly-timed manner, this would provide a more objective assessment of energy balance. The primary method to be used in dairy industry is a subjective measurement of the amount of body condition, termed as the body condition score (BCS). BCS is an internationally accepted, subjective visual and tactile measure of body condition (energy reserves) and temporal changes in BCS are used to monitor nutritional and health status of high producing cows during their productive cycle. (Berry et al., 2003)

BCS is a non-invasive way of assessing energy reserve of the animal (body fat), which is more precisely the metabolisable energy which gets stored in the muscle and fat of the animal body and are usually scored on a 5 point scale from 1 indicating thin to 5 indicating fat. (Edmonson et al., 1989)

So far, a number of periodic studies were conducted upon the monitorisation of BCS and its relationship with the metabolic profiles of cows at the same periparturient period. (Aktas et al., 2011) In the present study, therefore, the metabolic parameters viz., blood glucose, $\beta$-hydroxy butyrate (BHB) and blood urea nitrogen (BUN) of repeat breeding dairy cows with different BCS scores were investigated.

\section{Materials and Methods}

\section{Source of animals}

In this study, 136 healthy crossbred cows which failed to conceive after three consecutive inseminations with good quality semen and in their first to fifth parity were selected through mass contact programmes in and around the villages of Thiruvallur and Kanchipuram districts of Tamil Nadu, India. All the animals were subjected to rectal examination of reproductive tract to rule out any palpable abnormalities.

\section{Experimental design}

Body conditions was scored as fairly low (Group I: < 2.50 units; $\mathrm{n}=25$ ), moderate (Group II: 2.50 units; $\mathrm{n}=45$ ), good (Group III: 3.00 units; $n=44$ ), very good (Group IV: 3.50 units; $\mathrm{n}=18$ ) and over conditioned (Group V: > 3.50 units; $\mathrm{n}=4$ ) categories using a scale from 1 (emaciated) to 5 (obese), mainly assessed with 0.5 increments as described by Schröder and Staufenbiel (2006). (Schroder and Staufenbiel, 2006)

Blood samples $(3 \mathrm{~mL})$ were collected by jugular vein puncture into sterile microtubes (BD Vacutainer System, Plymouth, UK). After clotting at room temperature for 30 minutes and centrifugation (3000 g for 15 minutes at $4^{\circ} \mathrm{C}$ ) sera were carefully harvested and stored at $-20^{\circ} \mathrm{C}$ until analysis.

\section{Parameters studied}

The concentrations of blood glucose level were estimated using glucose test strips (One Touch $^{\circledR}$ Select ${ }^{\mathrm{TM}}$ glucometer test strips, Lifescan, Johnson \& Johnson pvt. Ltd., Mumbai, India) and $\beta$-hydroxybutyric acid (BHBA) were determined using the $\beta$ ketone test strip (Free Style Optium H $\beta$-Ketone test strips, Abbott Diabetes Care Inc, Abingdon, 
UK) (Heuer et al., 1999). The concentrations of serum blood urea nitrogen (BUN) determined using an automatic biochemical analyzer according to the manufacturer guidelines (Agappe Diagnostics Ltd., Agappe Hills, Kerala, India).

Serum concentrations of glucose, BHB and BUN of all BCS groups were analysed by oneway analysis of variance (ANOVA) using IBM $^{\circledR}$ SPSS $^{\circledR}$ Statistics software programme (version 20.0). The positive or negative correlations between all the blood parameters concerned and BCS were analysed by using Pearson's correlation coefficients.

The values were represented as the mean \pm standard error of the mean (SEM). Differences between the mean values of serum metabolites according to the BCS groups were considered non-significant when $\mathrm{P}>0.05$.

\section{Results and Discussion}

Serum biochemical values in relation to BCS groups were summarised in Table 1 . The overall mean glucose, BHB and BUN values are not correlated with BCS. There is no significant difference in the overall mean serum biochemical values according to different BCS categories. The mean blood glucose $(\mathrm{mg} / \mathrm{dL})$ ranged from $50.64 \pm 1.64$ to $56.61 \pm 4.49$.

The lowest blood glucose level was found in animals having BCS of 2.50 (group II) and the highest level was observed in cows with BCS 3.50. There was no significant difference in the blood glucose levels between groups.

The BHB (mmol/L) levels ranged from $0.40 \pm$ 0.11 to $0.55 \pm 0.05$. Maximum level of BHB was observed in cows having BCS of 3.50 and minimum level was found in cows having $\mathrm{BCS}>3.50$. There was no significant difference between groups.
The BUN (mg/dL) level ranged from $11.64 \pm$ 0.83 to $13.95 \pm 4.04$. Cows having BCS score of 3.00 had lower BUN levels and those with BCS > 3.50 had higher BUN levels. There was no significant difference between groups.

There was no correlation of body condition score with all three biochemical parameters viz. Blood glucose, BHB and BUN (Table 2).

BCS proved to be a useful tool for assessing the nutritive status of dairy cows (Hady et al., 1994) and is internationally accepted subjective visual and tactile measure of energy reserve. (Berry et al., 2003) In the present study animal with BCS of 3.5 has higher glucose level which indirectly reflect energy status of the cows.

Reece et al., (2015) suggested that blood glucose value between 40 to $80 \mathrm{mg} / \mathrm{dL}$ is required to maintain physiological processes of the body. In repeat breeder cows, Shiraz khan et al., (2010) observed glucose value of $38.81 \mathrm{mg} / \mathrm{dL}$ and Modi et al., (2017) found a value of $51.62 \mathrm{mg} / \mathrm{dL}$ which concurs with the present study. Ali et al., (2014) concluded that blood glucose could not be considered as absolute determinant of fertility.

The crossbred cows selected in the present study are low producing animals and hence glucose level cannot be considered as a determinant of fertility.

The BHB level in all the cows were within the reference value of less the $1.2 \mathrm{mmol} / \mathrm{L}$ indicative of positive energy balance. (Modi et al., 2017) In cows with BCS of more than 3.5 the BHB level was lowest $(0.40 \pm 0.11)$. However no significant correlation was observed between BCS and BHB in the study.

In our study the BUN value were within the normal range in all the cows in different group. 
Table.1 Mean \pm SE Serum biochemical parameters according to the BCS categories of repeat breeder dairy cows in early lactation period

\begin{tabular}{|c|}
\hline BCS \\
\hline$<2.5(25)$ \\
\hline $2.5(45)$ \\
\hline $3(44)$ \\
\hline $3.5(18)$ \\
\hline$>3.5(4)$ \\
\hline Overall \\
\hline F value \\
\hline
\end{tabular}

\begin{tabular}{|r|r|}
\hline Gluco & \\
\hline 50.8 \\
\hline 50.6 \\
\hline 50.8 \\
\hline 56.6 \\
\hline 53 \\
\hline 5 \\
\hline \\
\hline \\
\hline
\end{tabular}

Glucose $(\mathrm{mg} / \mathrm{dL})$
$50.88 \pm 1.88$
$50.64 \pm 1.64$
$50.84 \pm 1.78$
$56.61 \pm 4.49$
$53.25 \pm 4.07$
$51.62 \pm 1.05$
$0.898^{\mathrm{NS}}$

\begin{tabular}{|c|}
\hline Parameters \\
\hline BHB (mmol/L) \\
\hline $0.54 \pm 0.07$ \\
\hline $0.55 \pm 0.05$ \\
\hline $0.50 \pm 0.04$ \\
\hline $0.55 \pm 0.06$ \\
\hline $0.40 \pm 0.11$ \\
\hline $0.53 \pm 0.03$ \\
\hline $0.347^{\mathrm{NS}}$ \\
\hline
\end{tabular}

\begin{tabular}{|c|}
\hline BUN $(\mathrm{mg} / \mathrm{dL})$ \\
\hline $12.50 \pm 1.11$ \\
\hline $12.63 \pm 0.83$ \\
\hline $11.64 \pm 0.83$ \\
\hline $13.89 \pm 1.39$ \\
\hline $13.95 \pm 4.04$ \\
\hline $12.49 \pm 0.48$ \\
\hline $0.602^{\mathrm{NS}}$ \\
\hline
\end{tabular}

Table.2 Correlation between BCS and serum biochemical parameters (Blood glucose, BHB and BUN)

\begin{tabular}{|c|c|c|}
\hline Biochemical parameters & r value & Significance \\
\hline Blood glucose $(\mathrm{mg} / \mathrm{dL})$ & 0.107 & 0.214 \\
\hline BHB (mmol/L) & -0.053 & 0.542 \\
\hline BUN (mg/dL) & 0.039 & 0.655 \\
\hline
\end{tabular}

Ferguson et al., (1993) reported that blood urea nitrogen concentration greater than 20 $\mathrm{mg} / \mathrm{dL}$ is associated with lowest conception rate. Amle et al., (2014) observed BUN levels of $13.44 \pm 1.15 \mathrm{mg} / \mathrm{dL}$ in repeat breeder cows which concurs with our study.

Excess of degradable non-protein nitrogen in the absence of energy is converted to ammonia and excreted as BUN. Staples et al., (1990) suggested that negative association between BUN and reproductive outcome must be confounded by concurrent energy deficit. Vagneur (1996) recognised that urea is a very important indicator of nitrogen nutritional status. Since the BUN values were normal in all the animals no significant correlation could be recorded.

It can be concluded from the present study that even though BCS, blood glucose, BHB and BUN values reflected the nutritional status and metabolism no significant correlation was observed.

\section{Acknowledgment}

Authors gratefully acknowledge Indian Council of Agriculture, for providing financial support under All India Coordinated Research Project on "Nutritional and Physiological Interventions for Enhancing Reproductive Performance in Animals."

\section{References}

Aktas MS, Ozkanlar S, Ucar O, Ozkanlar Y, Kaynar O and Aytekin I (2011) Relationships between Body Condition Score and some metabolic blood parameters in early lactating dairy cows. Revue Méd. Vét., 12: 586-592.

Ali, A., M.S. Qureshi, M. Adil, A. Sikandar, Ihtesham-Ul-Haq, M.M. Awais, A. Hussain and A. Khan, 2014. Impact of blood metabolite profile and milk yield on fertility of dairy cows. J. Anim. Health Prod., 2(4): 55 - 59

Amle M, Patodkar V, Shelar R and Birade H (2014) Serum biochemical levels of 
repeat breeder cross bred cows under rural condition of Shatara District of Maharashtra. Int. J. Adv. Vet. Sci. Technol., 3: 109-113.

Berry DP, Buckley F, Dillon P, Evans RD, Rath $M$ and Veerkamp RF (2003) Genetic relationships among body condition score, body weight, milk yield, and fertility in dairy cows. Journal of Dairy Science, 86(6): 2193-2204.

Busato A, Faissler D, Kupfer U and Blum JW (2002) Body condition scores in dairy cows: associations with metabolic and endocrine changes in healthy dairy cows. Physiol. Pathol. Clin. Med., 49: 455-460.

Duffield TF, Lissemore KD, McBride BW and Leslie KE (2009) Impact of hyperketonemia in early lactation dairy cows on health and production. Journal of Dairy Science, 92(2): 571-580.

Edmonson AJ, Lean IJ, Weaver LD, Farver T and Webster G (1989) Abody condition scoring chart for Holstein dairy cows. Journal of Dairy Science, 72(1):68-78.

Ferguson JD, Galligan DT, Blanchard T and Reeves M (1993) Serum Urea Nitrogen and Conception Rate: The Usefulness of Test Information. Journal of Dairy Science, 76(12): 3742-3746.

Grummer RR (2007) Strategies to improve fertility of high yielding dairy farms: Management of the dry period. Theriogenology, 68: S281-S288.

Hady PJ, Domecq JJ and Kaneene JB (1994). Frequency and precision of body condition scoring in dairy cattle. Journal of Dairy Science, 77(6): 1543-1547.

Heuer C, Schukken YH and Dobbelaar P (1999)

Postpartum body condition score and results from the first test day milk as predictors of disease, fertility, yield, and culling in commercial dairy herds. Journal of Dairy Science, 82: 295-304.

Modi LC, Suthar BN, Sharma VK, Nakhashi HC, Panchasara HH and Modi F (2017) Comparative biochemical profile of blood serum and estrual mucus in normal and repeat breeding Kankrej cow. Indian Journal of Animal Health, 56(1): 53-58.

Reece WO, Erickson HH, Goff JP and Uemura EE (2015) Dukes' Physiology of Domestic Animals. 13 ${ }^{\text {th }}$ edn. John Wiley \& Sons, Inc. pp. 134

Roche JR, Friggens NC, Kay JK, Fisher MW, Stafford KJ and Berry DP (2009) Invited review: Body condition score and its association with dairy cow productivity, health, and welfare. Journal of Dairy Science, 92(12): 5769-5801.

Schroder UJ and Staufenbiel R (2006) Invited review: Methods to determine body fat reserves in the dairy cow with special regard to ultrasonographic measurement of back fat thickness. Journal of Dairy Science, 89: 1-14.

Shiraz khan, Thangavel A and Selvasubramaniyan S (2010). Blood biochemical profile in repeat breeding cows. Tamilnadu Journal of Veterinary \& Animal Sciences. 6(2): $75-80$.

Staples CR, Thatcher WW and Clark JH (1990) Relationship between Ovarian Activity and Energy Status during the Early Postpartum Period of High Producing Dairy Cows1, 2. Journal of Dairy Science, 73(4): 938-947.

Vagneur M (1996) Recommandations pour Ie rationnment des vaches laitires: evolution et informatisation. Bull Group Tech Vet, 5B, 491: 143-146.

\section{How to cite this article:}

Sameer Ali, M., K. Kulasekar, K. Krishnakumar and Chandrasekar, M. 2018. Influence of Metabolic Parameters in Repeat Breeding Crossbred Dairy Cows. Int.J.Curr.Microbiol.App.Sci. 7(08): 2460-2464. doi: https://doi.org/10.20546/ijcmas.2018.708.248 